\title{
Composition of Algal Oil and Its Potential as Biofuel
}

\author{
Pascal Schlagermann, ${ }^{1}$ Gerold Göttlicher, ${ }^{1}$ Robert Dillschneider, ${ }^{2}$ \\ Rosa Rosello-Sastre, ${ }^{2}$ and Clemens Posten ${ }^{2}$ \\ ${ }^{1}$ Department of Research and Innovation, EnBW Energie Baden-Württemberg AG, Durlacher Allee 93, 76131 Karlsruhe, Germany \\ ${ }^{2}$ Division of Bioprocess Engineering, Institute of Life Sciences, KIT Karlsruhe Institute of Technology, 76131 Karlsruhe, Germany
}

Correspondence should be addressed to Pascal Schlagermann, p.schlagermann@enbw.com

Received 8 November 2011; Revised 16 December 2011; Accepted 29 January 2012

Academic Editor: Panagiotis Grammelis

Copyright (C) 2012 Pascal Schlagermann et al. This is an open access article distributed under the Creative Commons Attribution License, which permits unrestricted use, distribution, and reproduction in any medium, provided the original work is properly cited.

\begin{abstract}
First test flights using blends with algae oil are already carried out and expectations by the aviation and other industries are high. On the other hand technical data about performance of cultivation systems, downstream processing, and suitability of algae oil as fuel are still limited. The existing microalgae growing industry mainly produces for the food and feed market. Energy efficiency is so far out of scope but needs to be taken into account if the product changes to biofuel. Energy and $\mathrm{CO}_{2}$ balances are used to estimate the potential of algae oil to fulfil the EU sustainability criteria for biofuels. The analysis is supported by lab tests as well as data gained by a pilot scale demonstrator combined with published data for well-known established processes. The algae oil composition is indicator of suitability as fuel as well as for economic viability. Approaches attaining high value fractions are therefore of great importance and will be discussed in order to determine the most intended market.
\end{abstract}

\section{Introduction}

The energy demand is growing worldwide. The total energy consumption has increased from $196 \mathrm{EJ}$ ( $10^{18}$ Joule) in 1973 to more than $350 \mathrm{EJ}$ in 2009 and the tendency is rising [1]. About $80 \%$ of this energy demand is delivered from fossil fuels with the consequence of an increase of greenhouse gas emissions in the atmosphere that provokes serious climate changes by global warming. Furthermore, the fossil fuels supplies are constantly diminishing. In consequence, the development of $\mathrm{CO}_{2}$-neutral fuels is one of the most urgent challenges facing our society and essential in order to meet the planned internationally specified targets, like the reduction of $\mathrm{CO}_{2}$ emissions in the range of $10-20 \%$ by 2020 (e.g., European Union). Therefore, there is an acute demand for sustainable, $\mathrm{CO}_{2}$-neutral resources to replace the demand of liquid fuels in the near future.

The potential of microalgae as renewable source for biofuel production is very promising due to higher growth rates and the capability to accumulate higher amounts of lipids (from $20 \%$ until $80 \%$ of dry weight) [2] than conventional oil crops (not more than $5 \%$ of dry weight) [3] and therefore the oil yield per hectare obtained from microalgae can greatly exceed the yield from oil plants like rapeseed, palm, or sunflower. Another advantage of microalgae over plants is their metabolic flexibility. That means that a variation in the biochemical composition of the biomass (towards higher lipid, carbohydrates or protein accumulation) can be regulated by varying the cultivation conditions [4]. Photobioreactors can be located on nonarable land and microalgae can grow in seawater or brackish water. Therefore, there is no competition for resources with classical agriculture. Furthermore, in large-scale applications production during the whole year will be possible employing effective process engineering tools for inoculation, maintenance, harvesting, and so forth, much more than possible in agriculture.

In general the water demand for the cultivation of microalgae is low in comparison with crops, especially when closed systems (photobioreactors) are applied. The production of 1 liter of biofuel from oil crops requires around 3,000 liters of water [5]. To obtain 1 liter of biofuel from microalgae with $50 \%$ lipid content, 10 to 20 liters are needed, taking into account the stoichiometric demand to fix $1 \mathrm{~mol} \mathrm{CO}_{2}$ from $1 \mathrm{~mol}$ of water during the photosynthesis and that the cells 
themselves consist of up to $85 \%$ of water [6]. Although the water demand is in practice much higher because reactor cooling is necessary in closed photobioreactors or for compensation of evaporation in open systems, the values are one to two orders of magnitude lower than for conventional agriculture [7]. These low values reconfirm the high potential and motivation for using microalgae as sustainable feedstock for biofuels.

The drawbacks of the current state of microalgal biotechnology are the high investments costs and the high demand on auxiliary energy for biomass production and for lipid processing to biodiesel leading to high costs for biomass and biodiesel. The use of residual nutrient sources and nutrient recycling are one of the keys for a sustainable production of biodiesel from microalgae. Wastewater can be used to supply nitrogen and phosphorus, main nutrients needed for the cultivation of algal biomass. The use of residual algal biomass after lipid extraction for example as feed (because of the high vitamin content) is a key factor in biorefinery concepts in order to improve economic feasibility. The rest biomass can be also fermented to produce methane or ethanol. Therefore, the ongoing research and development efforts are focused on the improvement of both the economic feasibility and sustainability for the production of biofuels from microalgae. The biorefinery concept of fermentation of the rest biomass to biogas will be included on the energy and $\mathrm{CO}_{2}$ balances shown in this paper.

\section{Energy and $\mathrm{CO}_{2}$ Balances for $\mathrm{CO}_{2}$ Capture Growing Microalgae}

2.1. Theoretical Potential for Energy Capture. Microalgae are phototrophic microorganisms. That means that they use $\mathrm{CO}_{2}$ as inorganic carbon source and sunlight as energy source to synthesize organic compounds. In this process called photosynthesis, $\mathrm{O}_{2}$ is released as a by-product. The overall equation of the oxygenic photosynthesis can be described as

$$
\mathrm{CO}_{2}+\mathrm{H}_{2} \mathrm{O} \stackrel{\text { sunlight }}{\longrightarrow}\left[\mathrm{CH}_{2} \mathrm{O}\right]+\mathrm{O}_{2},
$$

where $\left[\mathrm{CH}_{2} \mathrm{O}\right]$ represents the smallest building block of a carbohydrate and is the first organic product of photosynthesis. These sugar molecules are starting points for anabolic reactions to synthesize biomass compounds. Further auxiliary energy is required for these metabolic pathways. The organic carbon content in microalgae under nonlimiting nutrient conditions is about $50 \%$ by weight. In this case the stoichiometric $\mathrm{CO}_{2}$ demand is $1.83 \mathrm{~kg}(0.5 \cdot 44 \mathrm{~g} / \mathrm{mol}$ $\mathrm{CO}_{2} 12 \mathrm{~g} / \mathrm{mol} \mathrm{C}$ ) per each kilogram of dry algal biomass produced. Under accumulation of storage components like carbohydrates or lipids with different degrees of reduction the $\mathrm{CO}_{2}$ fixation varies between $1.65 \mathrm{~kg} \cdot \mathrm{kg}^{-1}(0.45 \cdot 44 \mathrm{~g} / \mathrm{mol}$ $\mathrm{CO}_{2} / 12 \mathrm{~g} / \mathrm{mol} \mathrm{C}$ ) for high starch content $(50 \%)$ and ca. $2.33 \mathrm{~kg} \cdot \mathrm{kg}^{-1}(0.634 \cdot 44 \mathrm{~g} / \mathrm{mol} \mathrm{CO} / 12 \mathrm{~g} / \mathrm{mol} \mathrm{C})$ for $50 \%$ lipid content respectively.

The conversion efficiency of light into biomass is expressed by the photoconversion efficiency (PCE) and is defined as the energy gained by a conversion process compared
TABLE 1: Microalgae biomass yield per square meter of surface area as function of PCE for three different solar irradiations assuming a lower heating value of $30 \mathrm{MJ} \cdot \mathrm{kg}^{-1}$ dry matter.

\begin{tabular}{|c|c|c|c|c|}
\hline & Germany & $\begin{array}{c}\text { Mediterranean } \\
\text { area }\end{array}$ & Dessert & \\
\hline PCE $\backslash$ Irradiation & 3,500 & 7,000 & 9,000 & $\mathrm{MJ} \cdot \mathrm{m}^{-2} \cdot \mathrm{a}^{-1}$ \\
\hline $1.0 \%$ & 1.2 & 2.3 & 3.0 & $\mathrm{~kg}_{\mathrm{DM}} \cdot \mathrm{m}^{-2} \cdot \mathrm{a}^{-1}$ \\
\hline $2.0 \%$ & 2.3 & 4.7 & 6.0 & $\mathrm{~kg}_{\mathrm{DM}} \cdot \mathrm{m}^{-2} \cdot \mathrm{a}^{-1}$ \\
\hline $3.0 \%$ & 3.5 & 7.0 & 9.0 & $\mathrm{~kg}_{\mathrm{DM}} \cdot \mathrm{m}^{-2} \cdot \mathrm{a}^{-1}$ \\
\hline $4.0 \%$ & 4.7 & 9.3 & 12.0 & $\mathrm{~kg}_{\mathrm{DM}} \cdot \mathrm{m}^{-2} \cdot \mathrm{a}^{-1}$ \\
\hline $5.0 \%$ & 5.8 & 11.7 & 15.0 & $\mathrm{~kg}_{\mathrm{DM}} \cdot \mathrm{m}^{-2} \cdot \mathrm{a}^{-1}$ \\
\hline
\end{tabular}

to the available sunlight supplied to the conversion process. In case of microalgae it is the ratio of the lower heating value of dry algae biomass divided by the sunlight supplied per ground area to the algae cultivation:

$$
\mathrm{PCE}=\frac{\text { biomass }\left[\mathrm{W} / \mathrm{m}^{2}\right]}{\text { sunlight }\left[\mathrm{W} / \mathrm{m}^{2}\right]} .
$$

Establishing maximal PCE under sunlight is of great interest because it implies attaining maximal biomass yield achievable from a given area of crop plantation or algal culture [4].

The theoretical biomass outputs as function of PCE for three different solar irradiations are given in Table 1.

The listed range In Table 1 from $1 \%$ to 5\% corresponds to the actually achieved PCEs on different cultivation systems and will be explained more detailed later on. The next paragraphs describe the maximal achievable PCE according to biological characteristics of microalgae.

The entire energy from incident sunlight cannot be converted into biomass because of several physiological properties from both microalgae and higher plants that reduce the efficiency of photosynthesis. Figure 1 shows the energy losses between the incident solar radiation and the formation of a carbohydrate. Because of the pigment absorption properties, only the photosynthetic active radiation (PAR) part from the whole solar radiation spectrum can be used for photosynthesis. The PAR consists of photons in the wavelength range between $400 \mathrm{~nm}$ and $700 \mathrm{~nm}$ resulting in a 55\% loss of the total incident radiation. The aim of light absorption by the pigments is to excite the chlorophyll molecules to eject electrons so that the radiation energy can be converted into chemically stored energy in form of ATP (adenosine tri phosphate) and $\mathrm{NADPH}_{2}$ (nicotinamide adenine dinucleotide phosphate). ATP and $\mathrm{NADPH}_{2}$ are needed to fix $\mathrm{CO}_{2}$ and to synthesize further biomass. Only photons with wavelengths of $680 \mathrm{~nm}$ and $700 \mathrm{~nm}$ (red) exhibit the exact energy content required for the excitation of chlorophyll. Higher frequency photons (blue) exhibit higher energy content as required and are used with less efficiency as red photons. Excess energy is dissipated as heat or fluorescence, a mechanism known as nonphotochemical quenching. Consequently, there is an energy loss of $21 \%$ of the absorbed PAR energy due to the degradation of PAR to the chlorophyll excitation energy at $700 \mathrm{~nm}$. Furthermore about 35\% energy losses are generated 

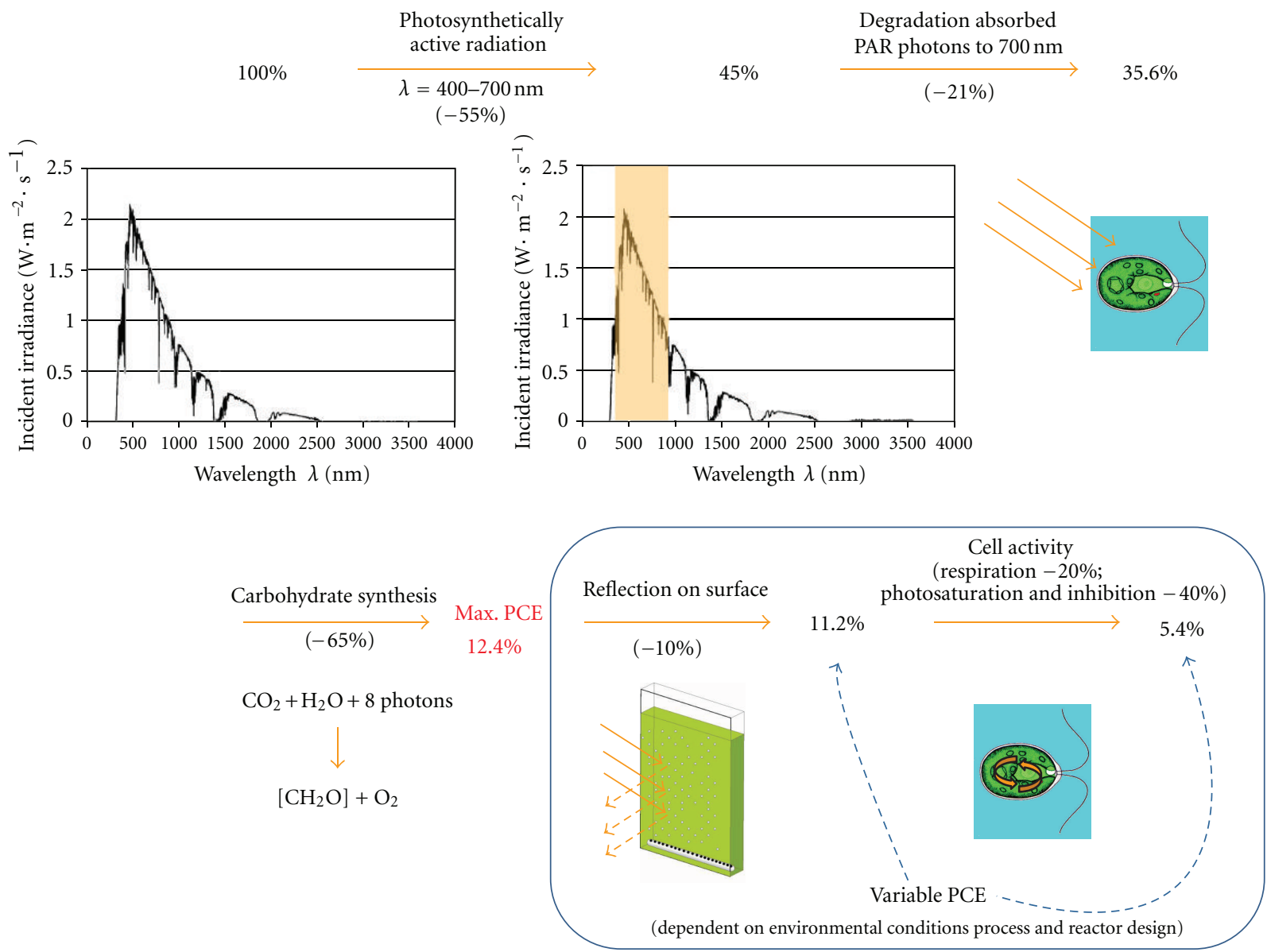

FIGURE 1: Effects causing energy losses during the conversion of sunlight into biomass (based on data from [4]).

by the several enzymatic steps needed for the fixation of $\mathrm{CO}_{2}$ into carbohydrate. In this case a photon demand of 8 photons to fix one mole of $\mathrm{CO}_{2}$ to carbohydrates is required [4].

The addition of all the energy losses described above, gives a theoretical maximum PCE of 12.4\% (see Figure 1), a value often referred to as photosynthetic efficiency (PE). The resulting achievable value of $\mathrm{PE}$ is independent of the photobioreactor technology or process strategy and cannot be improved by genetically engineering of the cells. Lipid production leads to an increase of the heating value of the biomass from $20 \mathrm{MJ} \cdot \mathrm{kg}^{-1}$ for oil-poor algae (between $20 \%$ and $30 \%$ dry weight) to $30 \mathrm{MJ} \cdot \mathrm{kg}^{-1}$ for oil-rich algae (50\% dry weight) [8]. For a constant PCE that leads to lower measured areal productivity in terms of dry mass. Furthermore, the photon demand will increase if proteins and lipids are synthesized reducing the PCE due to ineffective metabolic steps.

The real PCE in outdoor algal cultures decreases to a value between $1.5 \%$ and $5 \%$ depending on the photobioreactor system applied (race ways pond or closed systems), mixing conditions, and weather conditions. Reasons for the further losses of radiation are the reflection of light on water bodies at the reactor surface $(\sim 10 \%)$, photosaturation and photoinhibition $(\sim 40 \%)$, and respiration $(\sim 20 \%)$ [4]. If the PCE loss due to photosaturation can be reduced for example by means of light dilution (for further explanation see Subsection 2.3) short time PCE of $8 \%$ can be measured [9]. Usual PCE of crop biomass does not exceed 1\% PCE in temperate regions $[10,11]$ but can reach values of almost $4 \%$ during short-term experiments under optimized conditions [12]. Those maximum yields are peak values and hardly observed on average.

The PCE values mentioned above will be subject to further decrease during lipid production. If microalgae are cultivated under nitrogen limitation, they cannot synthesize the required protein and nucleic acid molecules for further growth and switch their metabolism towards the accumulation of energy and carbon reserve like starch or lipids depending on the algal strain. Lipid accumulation means that the photon demand to fix $\mathrm{CO}_{2}$ increases in comparison with starch accumulation because the synthesis of lipids from the first organic product of photosynthesis $\left(\mathrm{CH}_{2} \mathrm{O}\right)$ requires additional enzymatic steps.

No quantitative measurements or assessments of PCE values for growth during lipid synthesis can be found in the literature for the moment. On this area experimental works in labor scale are actually running at the Department of Bioprocess Engineering KIT as a part of a collaboration project with EnBW AG to obtain PCE values of the optimized process for lipid accumulation [13]. 
2.2. Biodiesel from Microalgae. Biodiesel is a mixture of fatty acids of diverse lengths esterified with an alcohol, typically methanol. Typical crop plants for biodiesel production are rapeseed, palm, sunflower, and soybean due to their high lipid content. Recent efforts to substitute microalgae biomass for these conventional crops are driven by the higher growth rates and lipid content of several algae species (Table 2). Biodiesel from microalgal feedstock might even be especially interesting for general aviation due to its good flow properties at low temperatures and high energy density.

The European norm EN 14214 gives an overview of biodiesel quality requirements and test methods. Table 3 shows a comparison of properties of microalgal oil, petroleum diesel, and norm standards.

The suitability of microalgal biomass as biofuel feedstock is closely related to the length and degree of saturation of its fatty acids as specified by the four key figures iodine value, oxidation stability, cetane number, and the cold filter plugging point. Beside other quality standards the feedstock needs to comply with target ranges defined by the European norm, which is fulfilled in case of algal biodiesel as shown in Table 3.

A high iodine number represents a high degree of unsaturation of fatty acids in biodiesel, which is unfavourable because fatty acids with higher content of double bonds are prone to oxidative damage. Otherwise, unsaturated fatty acids are beneficial for flow properties, especially at lower temperatures and therewith result in an advantageous cold filter plugging point. Lipids rich in long chain fatty acids with a low degree of saturation exhibit a high cetane number, indicating a short ignition delay time and high combustion quality whereas an exceeding degree of saturation might collide with the request for a reasonable cold filter plugging point by precipitation at low temperatures [15].

A comparison of fatty acid profiles of some selected algae strains and conventional biodiesel feedstock (Table 4) shows that there are fatty acids of comparable chain length extractable from all feedstocks whereas algae oils can contain considerably higher amount of polyunsaturated fatty acids. The resulting lower cold filter plugging point makes biodiesel from microalgae suitable as fuel for aviation. The fatty acid profile of microalgae and crops is not constant and varies depending on the culture conditions and the growth stage of the culture when harvested. Optimal culture conditions for the desired fatty acid profile can be easier regulated during the microalgal growth in photobioreactors than by oil crops on the landfill but at the cost of higher energy and $\mathrm{CO}_{2}$ demand. These conditions are species specific. No comparison data about the improve of quality for biodiesel in counterbalance with the higher energy demand for the regulation of optimal conditions are described at the moment in the literature and will not be considered for the energy and $\mathrm{CO}_{2}$ balances.

Strain selection can be performed with a special focus not only on generally applied selection criteria, such as lipid content and areal lipid productivity, but also on the fatty acid profiles matching biodiesel requirements. Further selection criteria for microalgae need to be considered as they mainly influence the ability to produce biomass at a large scale in the
TABLE 2: Lipid content of selected algae species [2].

\begin{tabular}{lc}
\hline Microalgae species & Lipid content (\% dry weight) \\
\hline Botryococcus braunii & $25-75 \%$ \\
Nannochloropsis sp. & $31-68 \%$ \\
Schizochytrium sp. & $50-77 \%$ \\
Neochloris oleoabundans & $35-54 \%$ \\
Nitzschia sp. & $45-47 \%$ \\
\hline
\end{tabular}

respective environments. Amongst them strain-specific optimal temperature range, salinity of the cultivation medium, and the ability to be maintained for longer periods in nonaxenic cultures need to be taken into account. Therefore, the choice of the most adequate cultivation system and process strategy will be decisive in order to achieve high areal lipid productivities. An overview and comparison of different types of reactors used nowadays for microalgae cultivation is given in the Subsection.

2.3. Microalgae Cultivation. Traditionally, microalgae are cultivated in the so-called open ponds, which are natural or artificial bodies of standing water typically 20 to $30 \mathrm{~cm}$ deep. The $\mathrm{CO}_{2}$ is taken from the atmosphere. The expected upper performance for open ponds is a PCE around $0.5 \%$, so basically not better than for terrestrial energy plants. The first means to increase productivity is better mixing, which can be achieved by employing paddle wheels to move the water through annular channels, thus improving gas transfer and bringing all cells to the bright surface at least statistically. In more recent applications an additional supply of $\mathrm{CO}_{2}$ is foreseen, leading to expected PCEs below 2\%. The current activities to produce biodiesel from microalgae are actually based on these raceway ponds because of their low costs and low demands on auxiliary energy when normalized to the pond volume. However, such open facilities exhibit high water evaporation per ground area ( 1 to $3 \mathrm{~m}^{3} \cdot \mathrm{m}^{-2}$ and year depending on the region) and a high risk of contamination. High evaporation allows operation without undermining the idea of using arid areas only by employing sea water algae and building the plant close to the sea or where brackish water is available [19]. Microalgal dry biomass concentrations do not usually exceed $2 \mathrm{~g} \cdot \mathrm{L}^{-1}$. This has a direct impact on the subsequent solid/liquid separation steps and on the demand of auxiliary energy for harvesting, which is high, normalized to the biomass produced.

To avoid these disadvantages the attention of research and application has shifted to closed photobioreactors. Here the culture volume is separated from the environment by transparent walls leading to less evaporation, less contact interface for possible invasion by competing microalgae, contaminating bacteria, or multicellular grassers or predators. Furthermore, $\mathrm{CO}_{2}$ can be applied very efficiently with only small losses in the off-gas and can be controlled close to the 1 to 2 mbar, which have been shown to be optimal for growth. Other values like $\mathrm{pH}$ or temperature could in principle be controlled as well, but current applications do not make much use of these options. However, there is a deeper 
TABLE 3: Comparison of selected properties of algal biooil and typical conventional diesel with respect to the European norm for biodiesel [14].

\begin{tabular}{|c|c|c|c|}
\hline Fuel property & Algal biodiesel & Petroleum diesel & EN14214 standard \\
\hline Higher heating value $(\mathrm{MJ} / \mathrm{kg})$ & 41 & 45.9 & - \\
\hline Kinematic viscosity $\left(\mathrm{mm}^{2} / \mathrm{s}\right) 40^{\circ} \mathrm{C}$ & 5.2 & $1.2-3.5$ & $3.5-5.2$ \\
\hline Density (kg/L) & 0.864 & $0.83-0.84$ & $0.86-0.90$ \\
\hline Carbon (wt\%) & 76 & 87 & - \\
\hline Hydrogen (wt\%) & $\leq 12,7$ & 13 & - \\
\hline Oxygen (wt\%) & $\geq 11,3$ & 0 & - \\
\hline Sulphur (wt\%) & 0 & $0.05 \max$ & $<10 \max .0,02$ \\
\hline Boiling point $\left({ }^{\circ} \mathrm{C}\right)$ & - & $180-340$ & - \\
\hline Flash point $\left({ }^{\circ} \mathrm{C}\right)$ & 115 & $60-80$ & $>101$ \\
\hline Cloud point $\left({ }^{\circ} \mathrm{C}\right)$ & - & -15 to 5 & - \\
\hline Pour point $\left({ }^{\circ} \mathrm{C}\right)$ & -12 & -35 to -15 & - \\
\hline Cetane number & - & 51 & $>51$ \\
\hline
\end{tabular}

TABLE 4: Fatty acid profiles of biodiesel feedstock (wt.\%) resulting from gas chromatographic analysis.

\begin{tabular}{|c|c|c|c|c|c|c|}
\hline Fatty acid & Double bound position ${ }^{2}$ & Rapeseed [15] & Sunflower [15] & Nannochloropsis salina [16] & $\begin{array}{l}\text { Phaeodactylum } \\
\text { tricornutum [17] }\end{array}$ & $\begin{array}{l}\text { Botryococcus } \\
\text { braunii [18] }\end{array}$ \\
\hline $\mathrm{C} 12: 0^{1}$ & - & - & - & 5.0 & - & 0.7 \\
\hline C14:0 & - & - & - & - & 4.5 & 0.8 \\
\hline C15:0 & - & - & - & 0.5 & - & 0.5 \\
\hline C16:0 & - & 4.9 & 6.2 & 37.5 & 25.8 & 21.0 \\
\hline C16:1 & 9 & - & 0.1 & 23.3 & 37.5 & 2.0 \\
\hline $\mathrm{C} 16: 2$ & 7,10 & - & - & - & - & 6.5 \\
\hline C16:3 & $7,10,13$ & - & - & - & - & 15.2 \\
\hline $\mathrm{C} 17: 0$ & - & - & - & 0.4 & - & 0.1 \\
\hline C18:0 & - & 1.6 & 3.7 & 0.9 & 1.3 & 2.9 \\
\hline C18:1 & 9 & 33.0 & 25.2 & 11.9 & - & 3.2 \\
\hline C18:2 & 9,12 & 20.4 & 63.1 & 1.5 & 5.1 & 13.6 \\
\hline C18:3 & $9,12,15$ & 7.9 & 0.2 & - & 2.0 & 33.0 \\
\hline C20:0 & - & - & 0.3 & 0.1 & - & 0.2 \\
\hline C20:1 & 11 & 9.3 & 0.2 & - & - & - \\
\hline C22:0 & - & - & 0.7 & - & - & 0.1 \\
\hline C20:4 & $5,8,11,14$ & - & - & 3.3 & 1.6 & - \\
\hline C20:5 & $5,8,11,14,17$ & - & - & 15.3 & 13.1 & - \\
\hline C22:0 & - & - & - & 0.4 & - & - \\
\hline C22:1 & 13 & 23.0 & 0.1 & - & - & - \\
\hline C24:0 & - & - & 0.2 & - & - & 0.2 \\
\hline C24:1 & 15 & - & - & - & - & - \\
\hline
\end{tabular}

${ }^{1}$ Fatty acid with chain length of 12 carbon atoms and 0 double bonds. The same nomenclature applies for all other fatty acids.

${ }^{2}$ Double bound position beginning from the carboxyl group.

reason why closed reactors achieve higher biomass concentrations and higher productivities than ponds. This can be understood by employing growth kinetics of the algae for designing photobioreactors. A typically growth kinetics depending on light irradiation plotted as photosynthetically active photon flux density (PFD) is shown in Figure 2. The basic point is that a linear increase with increasing light intensity is only achieved for low light conditions. Direct incident sunlight, as applied on open ponds, cannot be used by the algal cells or is even inhibiting.

In this situation closed reactors offer the option to "dilute" the light over a larger surface. In this way the algae cells are exposed only to a small fraction of the full sun light intensity and grow close to the point of their optimal efficiency, so that PCE of 5\% and under well-controlled conditions of up to $8 \%$ can be achieved [9]. However, such values have never been obtained for real hectares and real years. For quite some years large tubular reactor installations of more than one ha are in operation $[20,21]$, where the light dilution is obtained by glass tubes forming fences. Here the light dilution factor is given by the ratio of the illuminated glass surface and the foot print area. The medium is pumped through the pipes in turbulent flow. Fresh $\mathrm{CO}_{2}$ can be applied either pure or mixed with air. Such tubular reactors offer good productivities for 


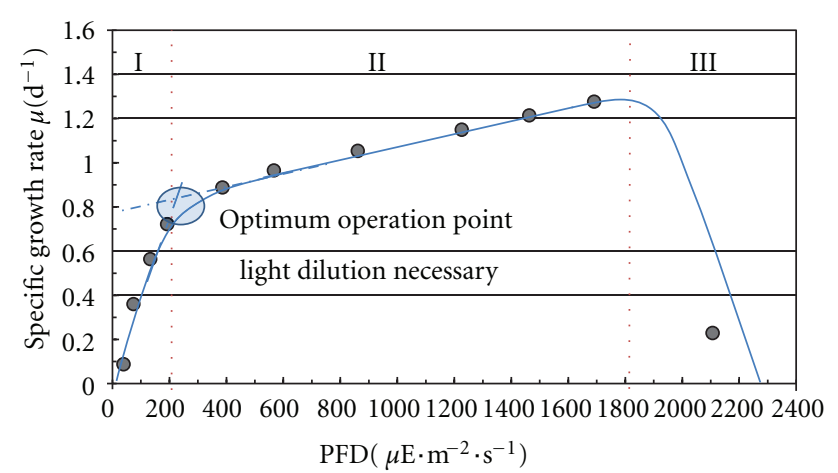

Figure 2: Specific growth rate as function of light irradiation plotted as photosynthetically active photon flux density (PFD) for Chlamydomonas reinhardtii; $1000 \mu \mathrm{E} \cdot \mathrm{m}^{-2} \cdot \mathrm{s}^{-1}$ corresponds approximately to $200 \mathrm{~W} \cdot \mathrm{m}^{-2}$. The PCE can be read as gradient from the origin to a given point on the curve. Therefore, PCE is at its optimum only in range I, where the circle indicates the point of highest growth rate.

high value products, but show other disadvantages. The costs for installation can go up to over several hundred $€$ per $\mathrm{m}^{2}$, being too high to ensure economic feasibility considering commodity markets. Furthermore, pumping energy exceeds several hundred or even thousand $\mathrm{W} \cdot \mathrm{m}^{-3}$, what prohibits energy positive microalgae production.

The second development line for closed photobioreactors is given by the so-called flat plate reactors. These designs consist basically of two parallel oriented vertical plates including the water body. Mixing and mass transfer are achieved by bubbles entering the single plates from the bottom similarly to bubble column or airlift reactors. Their solar light capturing surfaces consist of transparent materials with long shelf lives, for example, polyethylene (PE), polyvinylchloride (PVC, with some ecologic considerations) or poly(methyl methacrylate) (PMMA). In a simple case the plates are formed by plastic bags on scaffolds of mash wire, see Figure 3 . The light path length, defined as the thickness of the plate reactor, is in this case close to $10 \mathrm{~cm}$, but can vary in more recent designs between 1 and $5 \mathrm{~cm}$. Low cost and a comparatively small energy input of less than $100 \mathrm{~W} \cdot \mathrm{m}^{-3}$ make this reactor design in principle feasible for biofuel production. But still there is potential to achieve even better systems. The energy demand for bubbling can be reduced by choosing a low plate design, therewith reducing hydrodynamic pressure at the bottom of the reactor. To keep light dilution at a high level, the plates have to be arranged closer to each other. Furthermore, the smaller the total culture volume per footprint area (water coverage) is, the less energy is wasted for mixing. It is necessary to understand that the reaction volume is the intracellular space and not the chemically inactive medium between the cells. Consequently, a short light path length leads to low water coverage and high dry biomass concentrations. This demand for low height designs and low water coverage also supports a reduction of the material expenditure. Concluding, the energy input is one important cost factor and likewise significantly influences the net energy gain.
TABLE 5: Power input (excluding light) and algae biomass productivity in dry matter per cultivation volume and day of different reactors in outdoor experiments.

\begin{tabular}{lccc}
\hline Reactor type & $\begin{array}{c}\text { Power input } \\
{\left[\mathrm{W} \cdot \mathrm{m}^{-3}\right]}\end{array}$ & $\begin{array}{c}\text { Productivity } \\
\left(\mathrm{g} \cdot \mathrm{L}^{-1} \cdot \mathrm{d}^{-1}\right)\end{array}$ & Reference \\
\hline $\begin{array}{l}\text { Helical tube } \\
\text { reactor (outdoor) }\end{array}$ & 3,200 & 1.4 & {$[22]$} \\
$\begin{array}{l}\text { Bubble column } \\
\text { (outdoor) }\end{array}$ & 109 & $0.4(10$ days average) & {$[23]$} \\
Flat panel airlift & $100-200$ & circa 0.76 (average) & {$[24]$} \\
\hline
\end{tabular}

Table 5 gives an overview of power input of several reactors in outdoor experiments.

But there are other issues. Besides lower energy input especially the temperature problem has to be addressed. During outdoor operation the medium heats up during daytime depending on the changing irradiation and the air temperature. Microalgae, at least the strains usually cultivated nowadays, exhibit a quite narrow temperature growth profile. So cooling, for example, by spraying and evaporating water on the surface is necessary even in Middle-Europe in summer. One solution is to embed the plates in a separate water body, which at least dampen the temperature oscillations. The company Solix Biofuels [34] for example, cultivates algae in submerged flat plastic bags. The fundamental setup of the third-generation reactor concept $(3 \mathrm{G})$ is depicted in Figure 3. Major advantage of the submerged reaction compartments is the fact that additional temperature control is not necessary in the system because the surrounding water acts as temperature buffer. Moreover, construction costs for the reactor are reduced as there is no need for a special scaffold supporting the flat reaction compartments. According to the information given by the official website Solix produces 5,000 to 8,000 gallons of algal oil per acre, per year (circa 42 to $67 \mathrm{tha}^{-1} \cdot \mathrm{a}^{-1}$, assuming an oil density of $900 \mathrm{~kg} \cdot \mathrm{m}^{-3}$ ) [35]. A fourth generation reactor including membrane aeration is currently under development.

With regard to economic considerations investment costs should not exceed $20 € \cdot \mathrm{m}^{-2}$ for biofuel production and operating costs need to be minimized. A similar approach has been developed by Proviron [36] (Figure 4) and represents another applied advancement of classic flat plate reactors. Their major focus was set on development of an efficient low cost reactor suitable for large-scale outdoor applications. Their approach comprises the incorporation of flat growth compartments (less than $1 \mathrm{~cm}$ thick) within water-filled plastic bags without any rigid structure. The major part of the setup consists of water-filled chambers that are separated from the reaction compartments. Water diffuses the impinging solar radiation, which should result in an equalized light distribution within the water-filled chamber. At the same time, temperature is regulated without any additional energy input. Moreover, the water-filled chambers themselves constitute the scaffold of the reactor, analogous to Solix reactors. In the future the low auxiliary energy demand of $20 \mathrm{~kW} \cdot \mathrm{ha}^{-1}$ should be further reduced with control strategies that aim at an adaption of aeration to light. According to the company 

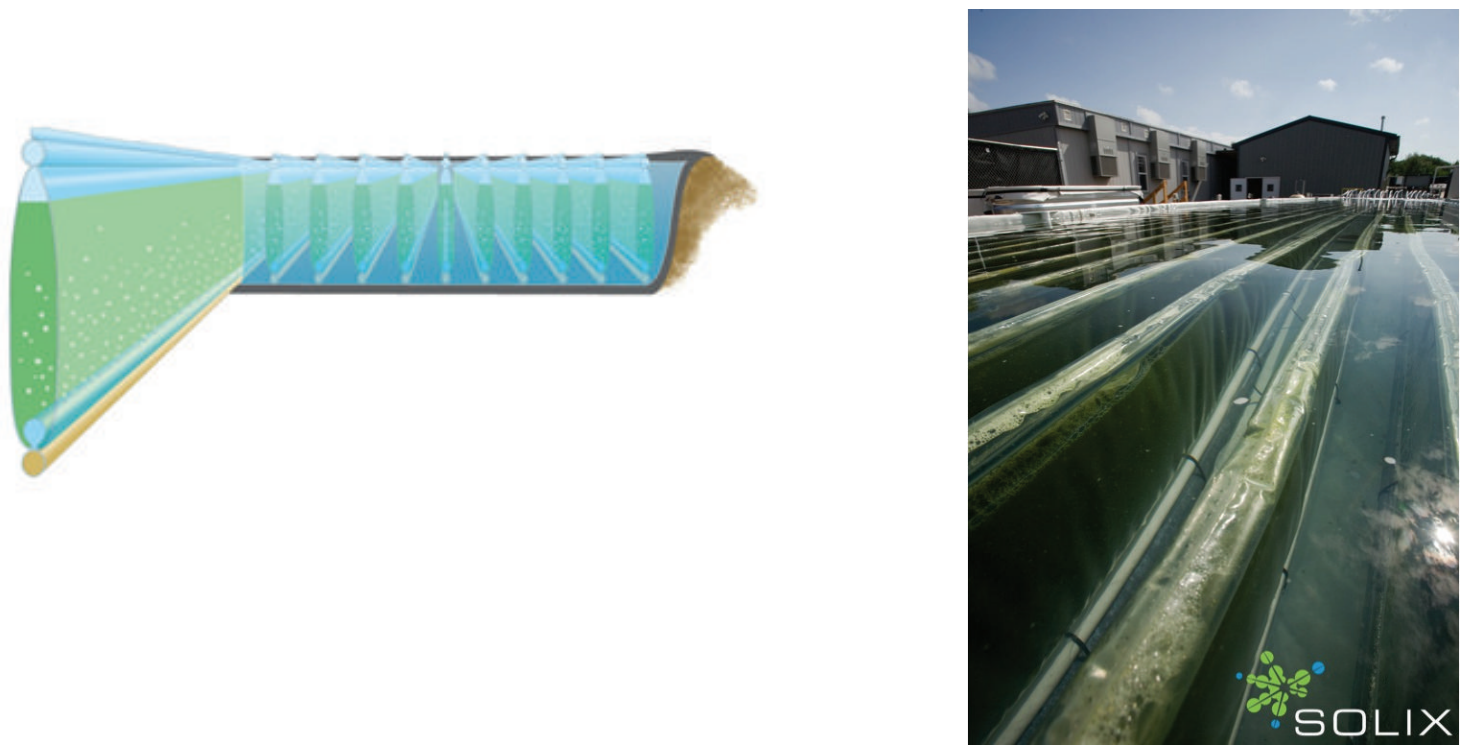

Figure 3: Solix Biofuels demonstration facility: schematic representation of the $3 \mathrm{G}$ reactor setup and photography of the production facility [34].
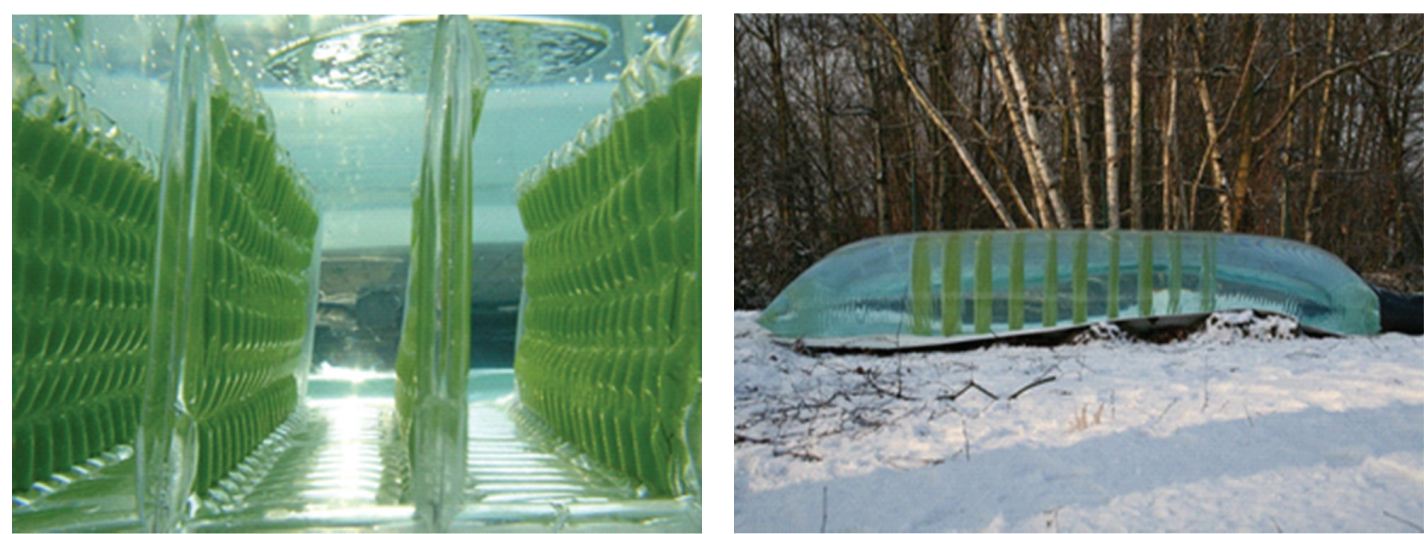

FIgURE 4: Submerged flat panels in a Proviron photobioreactor [36].

outlook investment costs are expected to drop from currently $200,000 € \cdot \mathrm{ha}^{-1}$ to $100,000 € \cdot \mathrm{ha}^{-1}$.

Besides sunlight and $\mathrm{CO}_{2}$ all systems need to be supplied with water and nutrition.

$\mathrm{CO}_{2}$ has in principle to be supplied in order to meet the stoichiometric demand of the cells and to keep the partial pressure in the medium at a level high enough with respect to the uptake kinetics to allow sufficient flow across the cell membrane. $\mathrm{CO}_{2}$ can be provided from industrial flue gases, for example, from biogas or gas combustion, while flue gas from hard coal combustion is less favourable because of heavy metal dust particles. Other $\mathrm{CO}_{2}$ sources can be found in chemical processes like lime kiln or ethylene factories.

In tubular reactors pure $\mathrm{CO}_{2}$ can be applied because mixing is done by pumps. In flat plate reactors, additional air is supplied for mixing purposes leading to a gas mixture of usually less than $10 \% \mathrm{CO}_{2}$ molar fraction. As no cheap and reliable $\mathrm{CO}_{2}$ sensors are available yet, $\mathrm{pH}$ is taken as controlled value. As the $\mathrm{pH}$ is also influenced by other factors (e.g., ammonia uptake) this is not always an optimum solution. $\mathrm{CO}_{2}$ feeding on demand, for example, with strongly reduced rates during the night is one option out of the tools of control engineering. Following the fluorescence signal given by the cells to optimize agitation and harvesting cycles on line is another idea under discussion. The cultivation process has to be controlled in a way that the nitrogen source (ammonia or nitrate) is depleted at the end of a first process phase, while the cells start to accumulate lipids. The exact timing of this switching process is another issue to be addressed during development of optimal production processes.

Future production processes will further integrate biology, process and control engineering, and environmental conditions. Further screening and genetic engineering is 
targeted to a fatty acid profile adapted to the technical needs. The above-mentioned light saturation can be diminished by the so-called antenna reduced mutants. While wild-type cells dissipate energy under high light conditions, these cells can take up only as many photons as they can process further in the metabolism. This makes higher cell densities and higher efficiencies in closed reactors possible. Other attempts to further enhance production are more extensive approaches to combine open ponds with light dilution by applying light conducting glass cones or other structures on the surface of creaks.

The span of the values for productivity and energy demand shown in Table 6 are usually based on pilot plant facilities. Linear extrapolation between productivity and energy demand is not possible. Firstly, productivities are influences by operational parameters themselves. High mixing energy supports high growth rates by better mass transfer, but also by the so-called intermittent light effect [37]. This phenomenon describes the abilities of the cells to store light energy in the time range of $\mathrm{ms}$, in this way making profit from fast mixing cycles between dark and light parts of the reactors. While a given reactor geometry with respect to light dilution may be optimal in a given region, it may be suboptimal in another, where higher light dilution is necessary on cost of higher energy and material demand. Secondly, a measured PCE cannot be simply applied to another production site. Even if light dilution is considered properly, the effect of environmental factors on the PCE value like temperature-usually assumed as being from Arrhenius type [38] — diffuse light, and day length can hardly be anticipated. Growth-model-based attempts for extrapolation using local weather data or landscape characteristics have nevertheless been proposed [39, 40] but not finally proven. Practical experiences are actually missing, whether the advantage of a higher irradiation of a maximum ratio of 2.5 between middle Europe and North Africa can really be exploited facing problems of temperature control, $\mathrm{CO}_{2}$ and nutrition logistics and higher light dilution factors. So there are already ideas to cultivate microalgae in moderate northern areas making use of long days with many sunny hours in the summer and switching off the plant in winter, a strategy that saves at least maintenance and operational energy.

2.4. Downstream Processing. The first step in product recovery is the harvesting of the biomass that comprises separation and dewatering of the algae cells. Dewatering in this context means removal of the intercellular medium to an extent of about $90 \%$ resulting in a pasty pumpable product, while the intracellular water $(>80 \%)$ keeps unchanged. Harvesting can be done in principle by filtration or centrifugation [41]. The task of solid/liquid separation in bioprocesses is not new as such including low value products like yeasts or bacteria. Therefore, applicable devices are available on the market. However, microalgal suspensions exhibit for the moment low solid concentration of less than, for example, $1 \mathrm{~g} \cdot \mathrm{L}^{-1}$ and a low added value with respect to biofuels. This fact leads to changes in operation of classical approaches towards lower energy consumption and also triggered the design of new separation devices (e.g., Evodos [42]).
TABLE 6: Cultivation-system-related parameters (own estimates based on/completed with $[9,25,26])$.

\begin{tabular}{lccc}
\hline & Raceway ponds & Closed systems & \\
\hline $\begin{array}{l}\text { Photoconversion } \\
\text { efficiency }\end{array}$ & 1.5 & 5 & $\%$ \\
$\begin{array}{l}\text { Typical biomass } \\
\text { concentration }\end{array}$ & 0.5 to 1 & 2 to 9 & $\mathrm{~kg} / \mathrm{m}^{3}$ \\
$\begin{array}{l}\text { Spec. energy } \\
\text { demand cultivation } \\
\text { (per area) }\end{array}$ & 0.5 to 4 & 2.5 to $15^{*}$ & $\mathrm{~W} / \mathrm{m}^{2}$ \\
\hline
\end{tabular}

* Based on the volumetric demand of 50 to $150 \mathrm{~W} / \mathrm{m}^{3}$ for closed systems and a volume/surface ratio from 0.05 to $0.1 \mathrm{~m}^{3} / \mathrm{m}^{2}[23,27]$.

Filtration is the classical method in bioseparation. Harvesting in open ponds is sometimes still done using manual sieves [43]. Press filtration is the standard operation procedure in sludge dewatering [44]. Filter aid drum filtration is applied to produce compressed yeast from yeast "milk" [44]. Basic problems are the compressible filter cakes with low specific permeability and the high maintenance demand. The process development to overcome these problems goes in two different directions. One is the application of shear forces tangential to the filtration membrane with the effect of shear forces to prevent the formation of a filter cake [45]. The other one is belt filtration with continuous cake removal and belt drying by pressing [46].

Centrifugation is regarded as the most effective separation method with respect to large scale $[20,47,48]$. As the separation principle depends on cell size and on specific weight, the problems are already charted. The cell diameter is of $5-10 \mu \mathrm{m}$ in the range of yeasts, which are usually separated by decanter centrifuges or disk stack separators [49]. This latter choice is often made for microalgae as well $[20,48]$. While the specific weight for yeast is in the range of $1.1 \mathrm{~kg} \cdot \mathrm{L}^{-1}$, the density of algae depends on the oil content and can go down to values lower than the water density, making centrifugation more and more difficult and leading to flotation as a better approach. Disk stack separators and also newly designed centrifugal devices especially for microalgae (e.g., Evodos [42]) are operated at, for example, 3,000$4,000 \mathrm{~g}$ to reduce cell damage and claim efficiencies even below $1 \mathrm{kWh} / \mathrm{m}^{3}$.

Prior to the application of separation devices a preconcentration can be employed. Flocculation can be used in order to ease the following dewatering steps. Diverse mineral salts (e.g., aluminium sulphate, ferric chloride) or organic polymers (chitosan) can serve as flocculants. However, addition of chemicals is expensive, can interfere with extraction, or is even regarded as harmful to the environment [29]. Autoflocculation, for example, by stopping aeration with the effect of a pH shift, might avoid these detriments. The success depends on the presence of polysaccharides or specific proteins on the cell surface and is therefore strain and process dependent.

Data for the energy demand of solid/liquid separation is given from the device suppliers in terms of energy per processes liquid volume, but what counts at the end is the energy 
demand per cell dry mass. In practice this means that the energy demand can vary by almost a factor of 100 comparing different cultivation techniques. Typical values for energy use in solid/liquid separation are given in Table 7.

Moreover, solid/liquid separation developments on the biological level could be helpful, like approaches for cultivation in biofilms attached on solid surfaces or the employment of filamentous algae, which can be harvested much easier than single cells in suspension culture.

The second step in product recovery after the harvesting of the biomass is the extraction of lipids and lipid conditioning to biodiesel. Microalgae contain two main classes of lipids, polar lipids (including phospholipids and glycolipids) and neutral lipids (mono-, di-, triglycerides, isoprenoids, and waxes). The latter are accumulated under stress conditions, like nitrogen limitation, and exhibit most desirable properties for conversion to biodiesel $[28,50]$. As described above, high specific lipid contents are attained on the expense of low biomass productivities [51]. These technical challenges must be approached by sophisticated cultivation strategies, such as phased or spatial separation of high biomass productivity and lipid accumulation in two different process phases or bioreactor compartments.

Conventional biodiesel processing of algae biomass requires harvesting of biomass, drying of the crude material, and subsequent hexane extraction of lipids. The latter are then subjected to a transesterification process. During this process the three fatty acids of one molecule triacylglyceride (TAG) consecutively react with alcohol, typically methanol provided in molar excess, to form fatty acid methyl esters (FAMEs) and glycerol. Figure 5 shows the steps for biodiesel processing.

To increase efficiency of the extraction process previous cell disruption can be taken into account in order to enhance solvent access to the storage lipids [50]. The higher content of algal polyunsaturated fatty acids may induce adverse side reactions during transesterification [55]. However, some of these fatty acids, for example, eicosapentaenoic acid (C20:5), attain higher prices on the healthcare, nutrition, or other markets $[26,56]$. Therefore, gentle transesterification conditions and an additional separation step of products could improve profitability of the overall process. This is especially true at an early stage of development while scales are not big enough to deteriorate prices but biofuels from microalgae are still more expensive than petroleum diesel.

Biomass with low residual water content is prerequisite for the typical transesterification with a homogenous base catalyst as the remaining water leads to undesirable saponification reactions. Soap formation also occurs in consequence of a high content of free fatty acids found in some algae and is to be prevented because saponification impairs the subsequent separation process and leads to partial consumption of the catalyst $[28,57,58]$. Although base catalysis is favoured due to faster reaction kinetics and requirement of lower reaction temperatures saponification can be avoided when acid catalysts are used instead of alkaline ones, acid or base catalysts necessitate an additional neutralization process step. However, further attempts aim at replacing homogenous with heterogeneous catalysts. The latter reduce complexity of
TABLE 7: Electricity demand and ratio of separation for different separation technologies (adapted data from $[9,25,26,28]$ ). A detailed review is available from [29].

\begin{tabular}{lccc}
\hline & Centrifuge & Filtration & \\
\hline Specific electricity demand & 3.6 to 14.4 & 1.8 & $\mathrm{MJ} / \mathrm{m}^{3}$ \\
Ratio of separation & 90 & 80 & $\%$ \\
\hline
\end{tabular}

the process, cost, and the use of hazardous chemicals because separation and recovery of the catalyst as well as neutralization are dispensable $[57,59,60]$.

Further attempts to introduce more fundamental changes in the overall process in order to replace toxic chemicals, for example, hexane, and to increase overall efficiency include extraction of lipids with supercritical carbon dioxide. In small-scale experiments extraction has proved to be efficient and shows energetic advantages over conventional extraction [50,61]. Applicability in larger scale requires further assessment and might be energy intensive due to the demand of high pressure. Carbon dioxide can be recycled after extraction or alternatively fed into photobioreactors. One additional advantage of this method is the ease of modification, for example, utilization of cosolvents, to attain certain selectivity in the extraction therewith enabling sequential extraction of different lipid classes. Experiments show that under specific process conditions triacylglycerides can be extracted with pure supercritical carbon dioxide in a first reaction step whereas phospholipids can be recovered only after addition of another solvent, such as ethanol [50].

A promising approach to eliminate the cost and energy intensive drying process of biomass suggests a two-step process that can be applied directly to wet biomass. In a first step lipids are hydrolysed inside the cells at high temperatures $\left(\right.$ ca. $250^{\circ} \mathrm{C}$ ) resulting in an easily filterable solid that contains the majority of free fatty acids while phosphorous and nitrogen can be recovered from the filtrate. In a second reaction step the retentate was subjected to the esterification with ethanol at supercritical conditions. The overall process therewith does not require the drying process, facilitates the straightforward recovery of nutrients, and eliminates the use of toxic chemicals [62].

2.5. Energy and $\mathrm{CO}_{2}$ Balances of Algal Biofuels. Calculations on the energy and $\mathrm{CO}_{2}$ balances for the production of biodiesel from microalgae on the base of the technological stateof-the-art for algal cultivation and lipid extraction will be shown in this section. The energy and $\mathrm{CO}_{2}$ balances are determined for both cultivation technologies: (i) raceway ponds and (ii) closed photobioreactors considering the process as given in Figure 6. After cultivation the microalgae are harvested. The oil is extracted and converted into biodiesel. The algae press cake is digested for biogas production. The biodiesel as well as the biogas is balanced to substitution of fossil fuel. As microalgae biodiesel production in an industrial scale does not exist, figures from commercial vegetable oil (production capacity of around 100,000 tons per year) conversion to biodiesel are used. 


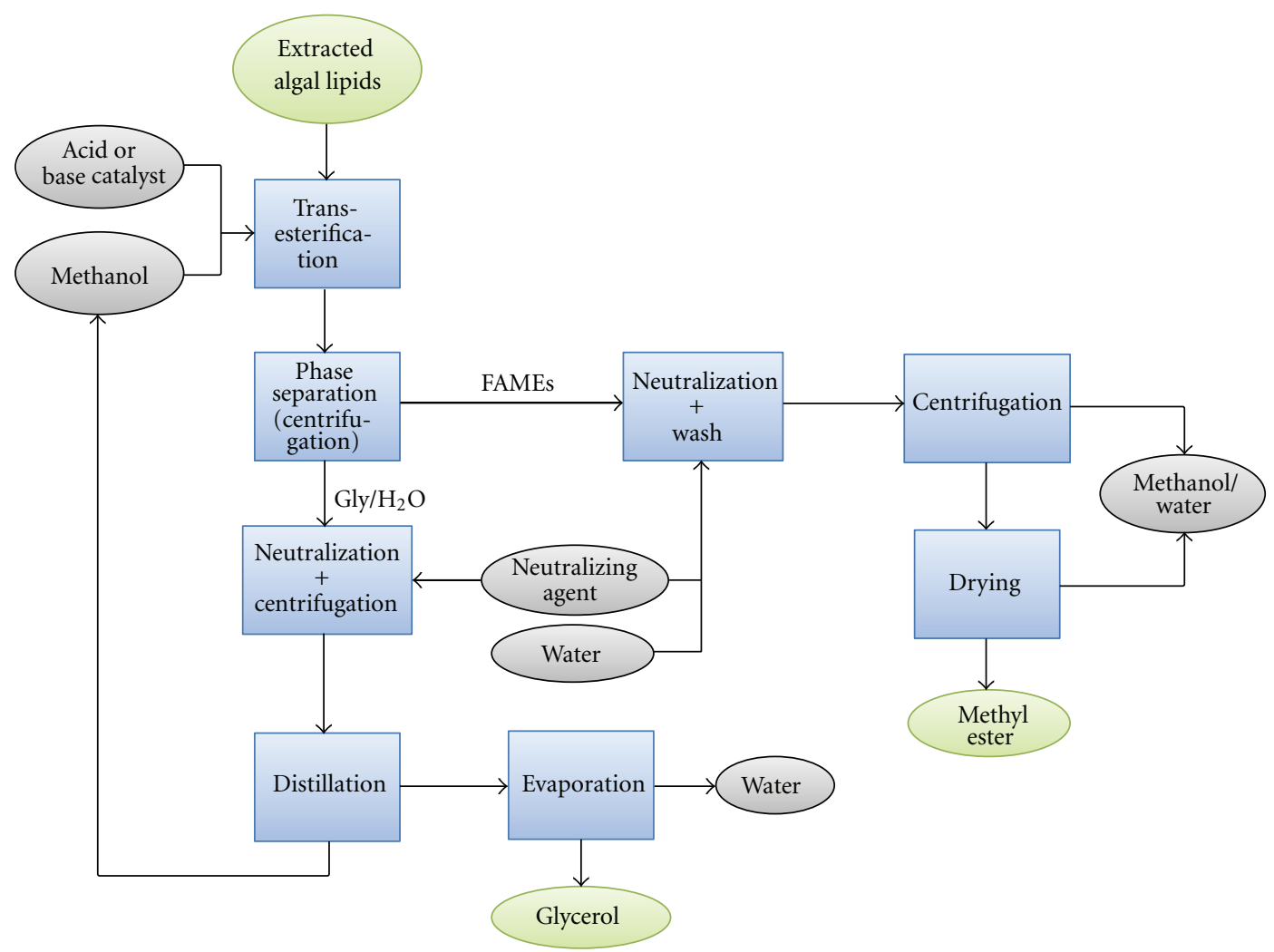

FIGURE 5: Scheme of conventional biodiesel processing [52-54].

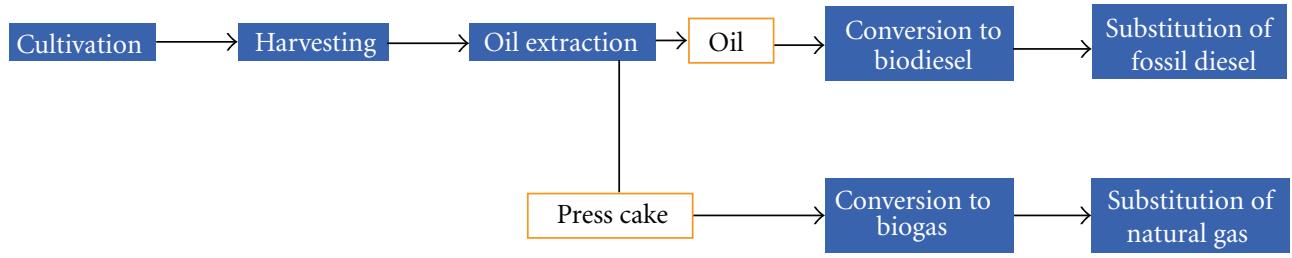

Figure 6: Scheme of evaluated value chain.

The results are presented for a solar radiation of $7,000 \mathrm{MJ} \cdot \mathrm{m}^{-2} \cdot \mathrm{a}^{-1}$ (corresponding to the radiation in Mediterranean area) and PCEs of 1.5\% for raceway ponds and 5\% for closed photobioreactors, which are good case scenarios. The specific energy demand for cultivation with raceway ponds is set to $1 \mathrm{~W} \cdot \mathrm{m}^{-2}$ surface area and mainly applies for mixing of the culture media. For closed photobioreactors it is set to $100 \mathrm{~W} \cdot \mathrm{m}^{-3}$ (corresponding to $5 \mathrm{~W} \cdot \mathrm{m}^{-2}$ ). As for raceway ponds the energy demand for closed photobioreactors is predominantly used for mixing and also for gas supply, and therefore in both cases it is exclusively electrical energy. Potential additional energy consumption for, for example, temperature control is neglected.

The technology of choice for harvesting is centrifugation as it is the state of the art today. Since harvesting microalgae with biomass concentrations of just a few g per litre of culture media strongly determines the feasibility of an energetic utilization, other options need to be considered in future.
The oil is assumed to be extracted with a yield and energy demand comparable to that of, for example, rape seed oil production. The energy demand for transesterification of the oil is set to $0.72 \mathrm{MJ}$ electric and $1.7 \mathrm{MJ}$ thermal per $\mathrm{kg}$ of oil in analogy to rapeseed oil [30]. Furthermore $0.1 \mathrm{~kg}$ of methanol is added and roughly $0.13 \mathrm{~kg}$ crude glycerine is produced for each $\mathrm{kg}$ of oil processed.

The specific $\mathrm{CO}_{2}$ emissions applied to the $\mathrm{CO}_{2}$ balances are $385 \mathrm{~g}$ per kWh electricity produced considering the European average and $260 \mathrm{~g}$ per $\mathrm{kWh}$ thermal energy assuming a natural gas fired boiler [31]. A summary of all input parameters is given in Table 8 . As described above, only the main processes cultivating and utilizing microalgae are taken into account while this work should not be considered as life cycle assessment.

The energy balances are shown in Figures 7 and 8. At first sight both cultivation technologies show a positive energy balance. The energy consumed compared to the energy 
TABLE 8: Summary of estimated parameters assumed for calculation ([9, 26, 30-33] and own calculations).

\begin{tabular}{|c|c|c|}
\hline PCE for raceway ponds & 1.5 & $\%$ \\
\hline Biomass concentration for cultivation with raceway ponds & 0.8 & $\mathrm{kgDM}^{*} / \mathrm{m}^{3}$ \\
\hline Electricity demand for cultivation with raceway ponds & 1 & $\mathrm{~W} / \mathrm{m}^{2}$ \\
\hline PCE for closed photobioreactors & 5 & $\%$ \\
\hline Biomass concentration for cultivation with closed photobioreactors & 4.0 & $\mathrm{kgDM} * / \mathrm{m}^{3}$ \\
\hline Specific reactor volume for cultivation with closed photobioreactors & 0.05 & $\mathrm{~m}^{3} / \mathrm{m}^{2}$ \\
\hline Electricity demand for cultivation with closed photobioreactors & 100 & $\mathrm{~W} / \mathrm{m}^{3}$ \\
\hline Lower heating value microalgae biomass & 30 & $\mathrm{MJ} / \mathrm{kgDM}^{*}$ \\
\hline $\mathrm{CO}_{2}$ bound in microalgae biomass & 2.5 & $\mathrm{kgCO}_{2} / \mathrm{kgDM}^{*}$ \\
\hline Lipid content of microalgae biomass TAG*** & 40 & $\%$ \\
\hline Lower heating value microalgae oil & 38.2 & $\mathrm{MJ} / \mathrm{kg}$ \\
\hline Lower heating value microalgae press cake & 23 & $\mathrm{MJ} / \mathrm{kgDM}^{*}$ \\
\hline Separation efficiency of centrifuge & 90 & $\%$ \\
\hline Electricity demand centrifuge & 3.6 & $\mathrm{MJ} / \mathrm{m}^{3}$ \\
\hline Oil separation efficiency & 90 & $\%$ \\
\hline Electricity demand for oil extraction & 0.35 & $\mathrm{MJ} / \mathrm{kgDM}^{*}$ \\
\hline Heat demand for oil extraction & 1.75 & $\mathrm{MJ} / \mathrm{kgDM}^{*}$ \\
\hline Conversion rate algae oil into biodiesel & 90 & $\%$ \\
\hline Electricity demand conversion to biodiesel & 0.043 & $\mathrm{MJ} / \mathrm{kg}$ \\
\hline Heat demand for conversion to biodiesel & 0.750 & $\mathrm{MJ} / \mathrm{kg}$ \\
\hline Lower heating value of biodiesel & 37 & $\mathrm{MJ} / \mathrm{kg}$ \\
\hline Conversion efficiency microalgae press cake to biogas & 90 & $\%$ \\
\hline Electricity demand conversion to biogas & 0.48 & $\mathrm{MJ} / \mathrm{nm}^{3 * *}$ \\
\hline Heat demand for conversion to biogas & 1.5 & $\mathrm{MJ} / \mathrm{nm}^{3 * *}$ \\
\hline Lower heating value biogas & 20 & $\mathrm{MJ} / \mathrm{nm}^{3 * *}$ \\
\hline $\mathrm{CO}_{2}$ emission of electricity & 107 & $\mathrm{gCO}_{2} / \mathrm{MJ}$ \\
\hline $\mathrm{CO}_{2}$ emission of heat & 72 & $\mathrm{gCO}_{2} / \mathrm{MJ}$ \\
\hline Lower heating value of fossil diesel & 42.5 & $\mathrm{MJ} / \mathrm{kg}$ \\
\hline $\mathrm{CO}_{2}$ emission of fossil diesel & 3.1 & $\mathrm{kgCO}_{2} / \mathrm{kg}$ \\
\hline Lower heating value of natural gas & 43.2 & $\mathrm{MJ} / \mathrm{kg}$ \\
\hline $\mathrm{CO}_{2}$ emission of natural gas & 2.4 & $\mathrm{kgCO}_{2} / \mathrm{kg}$ \\
\hline
\end{tabular}

${ }^{*}$ DM: dry matter; ${ }^{* *} \mathrm{~nm}^{3}:$ standard cubic meter, ${ }^{* * *}$ TAG: triacylglyceride.

yield for raceway ponds accounts for circa $70 \%$ and in case of closed photobioreactors for circa $77 \%$. Closed photobioreactors show a much higher yield per surface area and therefore might be favourable considering land use as well as water demand as mentioned earlier. Unfortunately, the positive energy balance does not withstand a closer look for both cases as it is comparing apples to oranges. Values shown are the lower heating values of microalgal biodiesel and biogas compared to the electricity and heat consumed for their production. Assuming a highly efficient combined cycle power plant with an electric efficiency of $60 \%$ leads to the conclusion that in both cases less power can be produced from the fuels as is needed for their generation. The additional heat needed for processing is even neglected. The most significant energy consuming process steps are cultivation and harvesting. Energy input for these needs to be significantly reduced if microalgae technology will enter the commodity market for sustainability but also for cost reasons.

Due to the high power demand compared to the energy yield the $\mathrm{CO}_{2}$ balances are also negative, as presented in Figure 9. Vast efforts need to be done to meet today's as well as futures European Union sustainability criteria for biofuels. Requested $\mathrm{CO}_{2}$ reductions are $35 \%$ today rising to $50 \%$ until 2017 and even $60 \%$ to 2018 [63]. Whether and how development of microalgae cultivation and harvesting technology will be capable of meeting these goals is open.

\section{Conclusion and Outlook}

The numerous benefits of biofuel generation from microalgae are motivation for further analysis and development: biomass yields of up to 100 to 150 tons dry matter per ha and year with lipid contents of around $40 \%$, biodiesel yields of 40 to 50 tons per ha and year by far exceed the most promising yields from land crops. Fresh water demand can be reduced applying closed photobioreactors, using brackish water or seawater by a factor of one to two orders of magnitude. Algae oil quality generally is suitable for biofuel production. Because of the high amount of polyunsaturated fatty acids, microalgal biofuel shows good flow properties under low temperatures reducing the risk of cold filter plugging and making it even suitable for aviation fuel. Special is the ability 


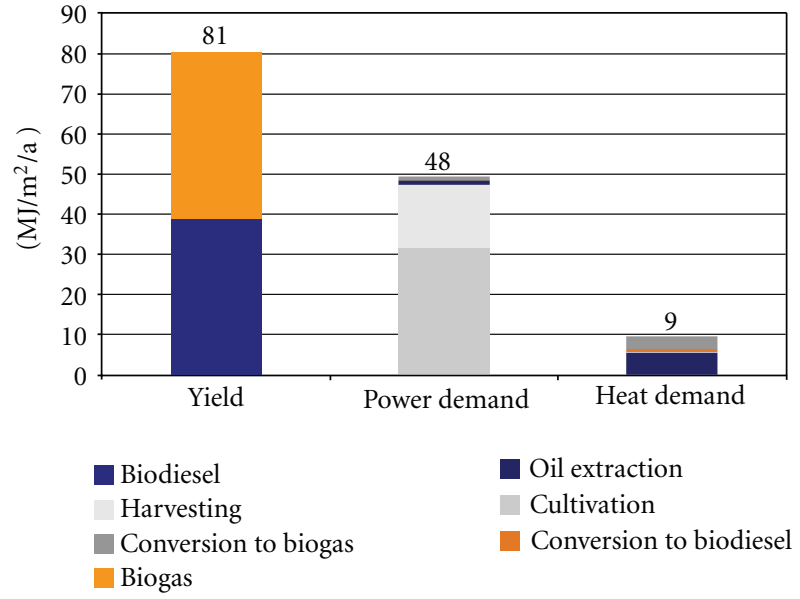

Figure 7: Comparison of energy yield and energy consumption producing biodiesel and biogas from microalgae applying raceway ponds (solar radiation $7,000 \mathrm{MJ} / \mathrm{m}^{2} / \mathrm{a}$ ).

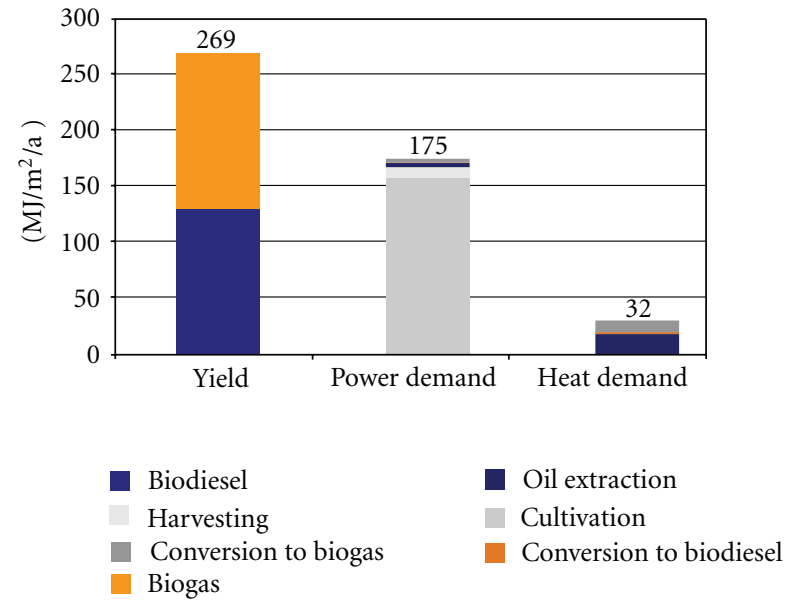

FIGURE 8: Comparison of energy yield and energy consumption for biodiesel and biogas production from microalgae applying closed photobioreactors (solar radiation $7,000 \mathrm{MJ} / \mathrm{m}^{2} / \mathrm{a}$ ).

to influence the oil composition by the selection of the strain cultivated and the cultivation conditions themselves. This might be one piece of the solution to overcome the so far bad economics.

State-of-the-art for cultivation systems are raceway ponds with low investment cost but also low yields producing for food and feed market while high value products are produced with closed photobioreactors accepting high costs sometimes even applying artificial lighting. Both systems are not optimized to commodity markets needs especially concerning low overall efficiency due to auxiliary energy demand, sophisticated process control, and low product concentrations. Reduced energy and water demand as well as cheap nutrient supply are of lower rank while high product quality is required. The energy as well as greenhouse gas balances for those production systems including downstream processing of the microalgae biomass into biofuels show negative results. Reasons are the excessive auxiliary power

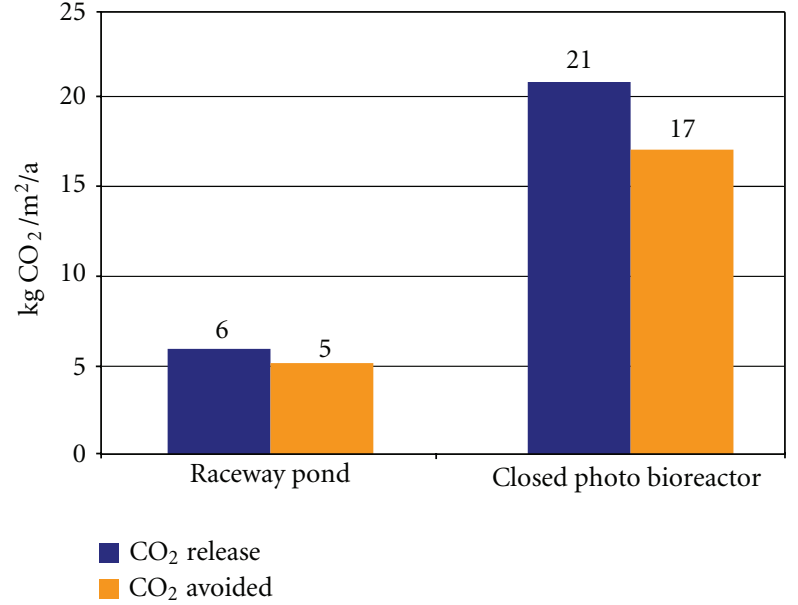

Figure 9: $\mathrm{CO}_{2}$ emissions released during microalgae biodiesel and biogas production compared to emissions avoided due to substitution of fossil fuels (solar radiation $7,000 \mathrm{MJ} / \mathrm{m}^{2} / \mathrm{a}$ ).

demand for cultivation and harvesting. At least a balanced scenario seems to be feasible assuming best case conditions. To meet the EU sustainability criteria for biofuels, which means a greenhouse gas emission reduction of at least 35\% today and $60 \%$ starting from 2018 , is from today's perspective very ambitious. Whether algae technology will be able to meet those targets is questionable.

However, key issues to meet commodity markets needs are identified and feasible solutions are under investigation. Closed photobioreactors show not only a much higher yield per surface area but also larger potential for process adaptation and control specific to the strain selected and products produced. Therefore, photobioreactors seem to be more promising. Possible solutions to reduce energy demand and increase yields are enhanced reactor designs, optimized process control, adapted separation technologies as well as integral concepts considering biology, process design for cultivation, and downstream processing to meet the different requirements for the specific target markets addressed in biorefinery concepts. But R\&D needs are still high to make algae technology a serious part of the solution of sustainable fuel supply in future. Although pilot projects are ongoing so far, there is no demonstration facility where such measures are implemented showing the promised performance and cost reductions or even being suitable for up scaling.

\section{References}

[1] IEA, "Key world energy statistics 2011," 2011.

[2] P. Schenk et al., "Second generation biofuels: high-efficiency microalgae for biodiesel production," BioEnergy Research, vol. 1, pp. 20-43, 2008.

[3] H. M. Amaro, A. C. Guedes, and F. X. Malcata, "Advances and perspectives in using microalgae to produce biodiesel," Applied Energy, vol. 88, no. 10, pp. 3402-3410, 2011.

[4] M. R. Tredici, "Photobiology of microalgae mass cultures: understanding the tools for the next green revolution," Biofuels, vol. 1, no. 1, pp. 143-162, 2010. 
[5] C. de Fraiture, M. Giordano, and Y. Liao, "Biofuels and implications for agricultural water use: blue impacts of green energy," Water Policy, vol. 10, no. 1, pp. 67-81, 2008.

[6] C. F. Murphy and D. T. Allen, "Energy-water nexus for mass cultivation of algae," Environmental Science and Technology, vol. 45, no. 13, pp. 5861-5868, 2011.

[7] R. H. Wijffels and M. J. Barbosa, "An outlook on microalgal biofuels," Science, vol. 329, no. 5993, pp. 796-799, 2010.

[8] M. Morweiser, O. Kruse, B. Hankamer, and C. Posten, "Developments and perspectives of photobioreactors for biofuel production," Applied Microbiology and Biotechnology, vol. 87, no. 4, pp. 1291-1301, 2010.

[9] N. H. Norsker, M. J. Barbosa, M. H. Vermuë, and R. H. Wijffels, "Microalgal production - A close look at the economics," Biotechnology Advances, vol. 29, no. 1, pp. 24-27, 2011.

[10] J. S. Boyer, "Plant productivity and environment (crop genetic improvement)," Science, vol. 218, no. 4571, pp. 443-448, 1982.

[11] C. Posten and G. Schaub, "Microalgae and terrestrial biomass as source for fuels-a process view," Journal of Biotechnology, vol. 142, no. 1, pp. 64-69, 2009.

[12] J. Coombs, Ed., Appendix C: Biomass Production and Data, Techniques in Bioproductivity and Photosynthesis, Pergamon Press, Oxford, UK, 2nd edition, 1985.

[13] http://bicycle.wtbk.org/.

[14] L. Brennan and P. Owende, "Biofuels from microalgae-a review of technologies for production, processing, and extractions of biofuels and co-products," Renewable and Sustainable Energy Reviews, vol. 14, no. 2, pp. 557-577, 2010.

[15] M. J. Ramos, C. M. Fernández, A. Casas, L. Rodríguez, and Á. Pérez, "Influence of fatty acid composition of raw materials on biodiesel properties," Bioresource Technology, vol. 100, no. 1, pp. 261-268, 2009.

[16] R. Huerlimann, R. de Nys, and K. Heimann, "Growth, lipid content, productivity, and fatty acid composition of tropical microalgae for scale-up production," Biotechnology and bioengineering, vol. 107, no. 2, pp. 245-257, 2010.

[17] H. Jiang and K. Gao, "Effects of lowering temperature during culture on the production of polyunsaturated fatty acids in the marine diatom Phaeodactylum tricornutum (Bacillariophyceae)," Journal of Phycology, vol. 40, no. 4, pp. 651-654, 2004.

[18] N. O. Zhila, G. S. Kalacheva, and T. G. Volova, "Effect of salinity on the biochemical composition of the alga Botryococcus braunii Kütz IPPAS H-252," Journal of Applied Phycology, pp. 1-6, 2010.

[19] E. Sartori, "A critical review on equations employed for the calculation of the evaporation rate from free water surfaces," Solar Energy, vol. 68, no. 1, pp. 77-89, 2000.

[20] Roquette Klötze GmbH \& Co. KG, Klötze, Germany, http:// www.algomed.de/index.php?op=algenfarm.

[21] Algatechnologies, Ltd, Kibbutz Ketura, Israel, 1998, http:// www.algatech.com/about.htm.

[22] D. O. Hall, F. G. Acién Fernández, E. C. Guerrero, K. K. Rao, and E. M. Grima, "Outdoor helical tubular photobioreactors for microalgal production: modeling of fluid-dynamics and mass transfer and assessment of biomass productivity," Biotechnology and Bioengineering, vol. 82, no. 1, pp. 62-73, 2003.

[23] A. Sánchez Mirón, M. C. Cerón García, F. García Camacho, E. Molina Grima, and Y. Chisti, "Growth and biochemical characterization of microalgal biomass produced in bubble column and airlift photobioreactors: studies in fed-batch culture," Enzyme and Microbial Technology, vol. 31, no. 7, pp. 1015-1023, 2002.
[24] P. Ripplinger, Industrielle Produktion von Mikroalgenbiomasse mit einem Flat-Panel-Airlift-Photobioreaktor, 5. Köthener Biotechnologie-Kolloquium, Köthen, Germany, 2009.

[25] D. Eyler and C. Posten, "Use of an algae bioreactor to reduce $\mathrm{CO}_{2}$ emissions and to produce biomass and/or biofuel," European Institute for Energy Research Karlsruhe, Karlsruhe, Germany, 2009.

[26] E. Molina Grima, E. H. Belarbi, F. G. Acién Fernández, A. Robles Medina, and Y. Chisti, "Recovery of microalgal biomass and metabolites: process options and economics," Biotechnology Advances, vol. 20, no. 7-8, pp. 491-515, 2003.

[27] E. Sierra, F. G. Acién, J. M. Fernández, J. L. García, C. González, and E. Molina, "Characterization of a flat plate photobioreactor for the production of microalgae," Chemical Engineering Journal, vol. 138, no. 1-3, pp. 136-147, 2008.

[28] H. C. Greenwell, L. M. L. Laurens, R. J. Shields, R. W. Lovitt, and K. J. Flynn, "Placing microalgae on the biofuels priority list: a review of the technological challenges," Journal of the Royal Society Interface, vol. 7, no. 46, pp. 703-726, 2010.

[29] N. Uduman, Y. Qi, M. K. Danquah, G. M. Forde, and A. Hoadley, "Dewatering of microalgal cultures: a major bottleneck to algae-based fuels," Journal of Renewable and Sustainable Energy, vol. 2, no. 1, article 012701, 2010.

[30] F. Müller-Langer et al., "Analyse und Evaluierung von Anlagen und Techniken zur Produktion von Biokraftstoffen," Institute für Energy and Environment, Dresden, Germany, 2007.

[31] S. Schmidt, Wirtschaftliche perspektiven der $\mathrm{CO}_{2}$-bindung durch algen und photokatalyse, M.S. thesis, Duale Hochschule Karlsruhe, Karlsruhe, Germany, 2010.

[32] J. Li, D. Zhu, J. Niu, S. Shen, and G. Wang, "An economic assessment of astaxanthin production by large scale cultivation of Haematococcus pluvialis," Biotechnology Advances, vol. 29, no. 6, pp. 568-574, 2011.

[33] K. K. Hildner, Konstruktion und Evaluation eines geschlossenen Plattenphotobioreaktors zur Kultivierung von Mikroalgen, M.S. thesis, University of Applied Sciences Amberg-Weiden, Hochschule, Germany, 2010.

[34] Solix BioSystems, Inc., Fort Collins, Colo, USA, http://www .solixbiofuels.com/.

[35] K. M. Weyer, D. R. Bush, A. Darzins, and B. D. Willson, "Theoretical maximum algal oil production," Bioenergy Research, vol. 3, no. 2, pp. 204-213, 2010.

[36] Proviron Industries NV, Hemiksem, Belgium, http://www .proviron.com/showcase/latest-proviapt-evolution-inaugurated.

[37] J. U. Grobbelaar, L. Nedbal, and V. Tichy, "Influence of high frequency light/dark fluctuations on photosynthetic characteristics of microalgae photoacclimated to different light intensities and implications for mass algal cultivation," Journal of Applied Phycology, vol. 8, no. 4-5, pp. 335-343, 1996.

[38] G. A. Alexandrov and Y. Yamagata, "A peaked function for modeling temperature dependence of plant productivity," Ecological Modelling, vol. 200, no. 1-2, pp. 189-192, 2007.

[39] S. C. James and V. Boriah, "Modeling algae growth in an openchannel raceway," Journal of Computational Biology, vol. 17, no. 7, pp. 895-906, 2010.

[40] J. Quinn, L. de Winter, and T. Bradley, "Microalgae bulk growth model with application to industrial scale systems," Bioresource Technology, vol. 102, no. 8, pp. 5083-5092, 2011.

[41] R. Harun, M. Singh, G. M. Forde, and M. K. Danquah, "Bioprocess engineering of microalgae to produce a variety of consumer products," Renewable and Sustainable Energy Reviews, vol. 14, no. 3, pp. 1037-1047, 2010. 
[42] Evodos, 2011, http://www.evodos.eu/market-specific-solutions/ totally-dewatering-algae.html.

[43] M. Thein, "The use of natural resource for sustainable production of Spirulina in Myanmar crater lakes," in Proceedings of the 5th International Algae Congress, Microalgae \& Biomass, Berlin, Germany, 2011.

[44] C. Posten, Principles of Mechanical Bioseparation, Shaker Verlag, Kaiserstraße, Germany, 2007.

[45] ANDRITZ KMPT GmbH, Vierkirchen, Germany, http://www .kmpt.com/nc/en/products/crossflow-filter-dcf/.

[46] Algaeventure systems, Marysville, Ohio, USA, http://algaevs .com/.

[47] GEA Mechanical Equipment, Düsseldorf, Germany, http:// www.gea-mechanical-equipment.com/markets-products/products/separators.html.

[48] Seambiotic Ltd., Tel Aviv, Israel, http://www.seambiotic.com/ home-2/.

[49] M. R. Ladisch, Bioseparations Engineering, Wiley Interscience, New York, NY, USA, 2001.

[50] L. Soh and J. Zimmerman, "Biodiesel production: the potential of algal lipids extracted with supercritical carbon dioxide," Green Chemistry, vol. 13, no. 6, pp. 1422-1429, 2011.

[51] J. Pruvost, G. Van Vooren, B. Le Gouic, A. Couzinet-Mossion, and J. Legrand, "Systematic investigation of biomass and lipid productivity by microalgae in photobioreactors for biodiesel application," Bioresource Technology, vol. 102, no. 1, pp. 150$158,2011$.

[52] A. Bouaid, Y. Diaz, M. Martinez, and J. Aracil, "Pilot plant studies of biodiesel production using Brassica carinata as raw material," Catalysis Today, vol. 106, no. 1-4, pp. 193-196, 2005.

[53] M. J. Haas, A. J. McAloon, W. C. Yee, and T. A. Foglia, "A process model to estimate biodiesel production costs," Bioresource Technology, vol. 97, no. 4, pp. 671-678, 2006.

[54] J. M. N. van Kasteren and A. P. Nisworo, "A process model to estimate the cost of industrial scale biodiesel production from waste cooking oil by supercritical transesterification," Resources, Conservation and Recycling, vol. 50, no. 4, pp. 442458, 2007.

[55] T. Bruton, H. Lyons, Y. Lerat, M. Stanley, and M. BoRasmussen, "A review of the potential of marine algae as a source of biofuel in Ireland," Tech. Rep., Sustainable Energy Ireland, 2009.

[56] Z. Y. Wen and F. Chen, "Heterotrophic production of eicosapentaenoic acid by microalgae," Biotechnology Advances, vol. 21, no. 4, pp. 273-294, 2003.

[57] B. Liu and Z. Zhao, "Biodiesel production by direct methanolysis of oleaginous microbial biomass," Journal of Chemical Technology and Biotechnology, vol. 82, no. 8, pp. 775-780, 2007.

[58] A. Singh, P. S. Nigam, and J. D. Murphy, "Mechanism and challenges in commercialisation of algal biofuels," Bioresource Technology, vol. 102, no. 1, pp. 26-34, 2011.

[59] S. Gryglewicz, "Rapeseed oil methyl esters preparation using heterogeneous catalysts," Bioresource Technology, vol. 70, no. 3, pp. 249-253, 1999.

[60] G. J. Suppes, M. A. Dasari, E. J. Doskocil, P. J. Mankidy, and M. J. Goff, "Transesterification of soybean oil with zeolite and metal catalysts," Applied Catalysis A, vol. 257, no. 2, pp. 213 223, 2004.

[61] L. B. Brentner, M. J. Eckelman, and J. B. Zimmerman, "Combinatorial life cycle assessment to inform process design of industrial production of algal biodiesel," Environmental Science and Technology, vol. 45, no. 16, pp. 7060-7067, 2011.
[62] R. B. Levine, T. Pinnarat, and P. E. Savage, "Biodiesel production from wet algal biomass through in situ lipid hydrolysis and supercritical transesterification," Energy and Fuels, vol. 24, no. 9, pp. 5235-5243, 2010.

[63] European Parliament Council, "Directive 2009/28/EC of the European Parliament and of the Council of 23 April 2009 on the promotion of the use of energy from renewable sources and amending and subsequently repealing Directives 2001/ 77/EC and 2003/30/EC," Tech. Rep. COD(2008)0016, Official Journal of the European Union, 2008. 

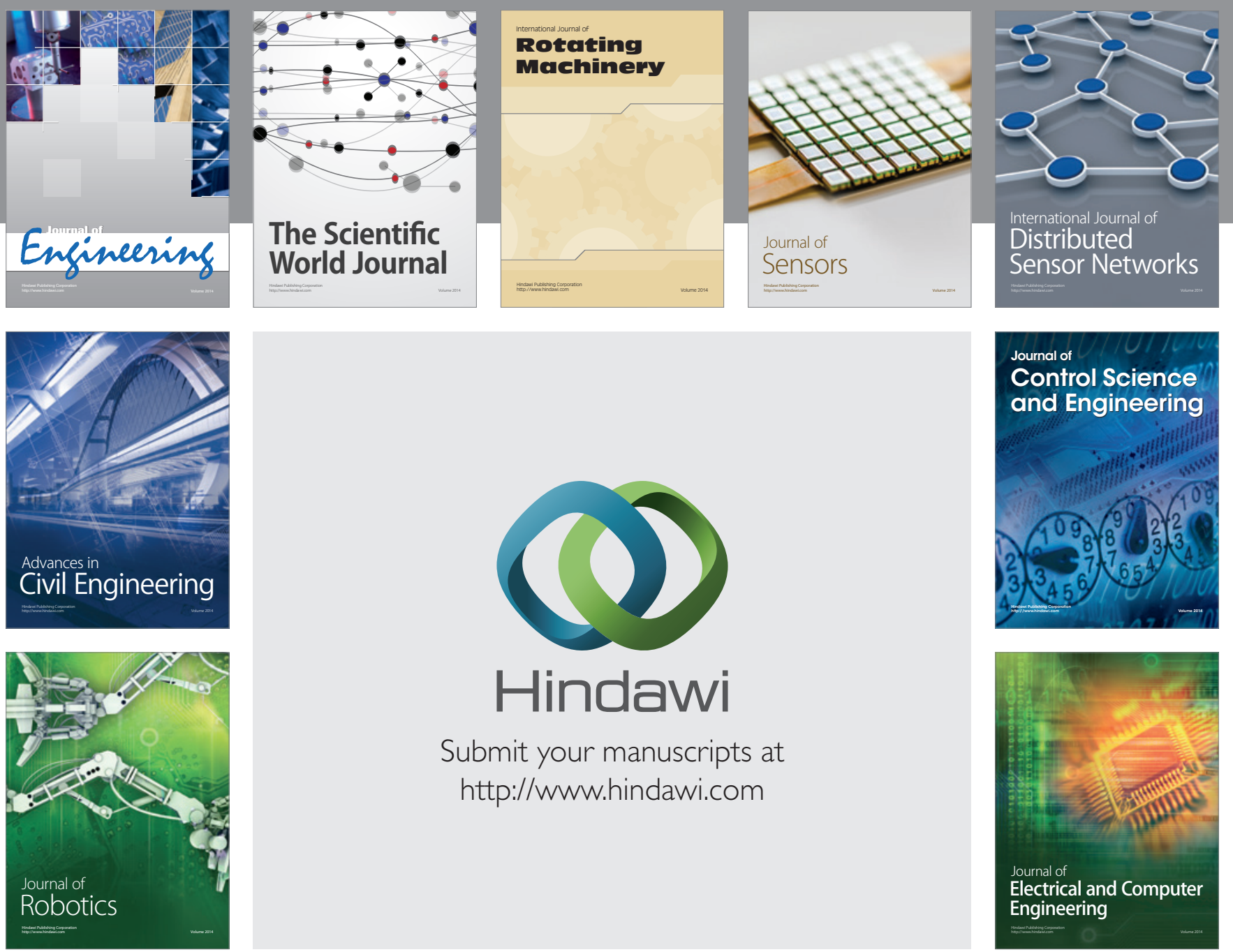

Submit your manuscripts at

http://www.hindawi.com
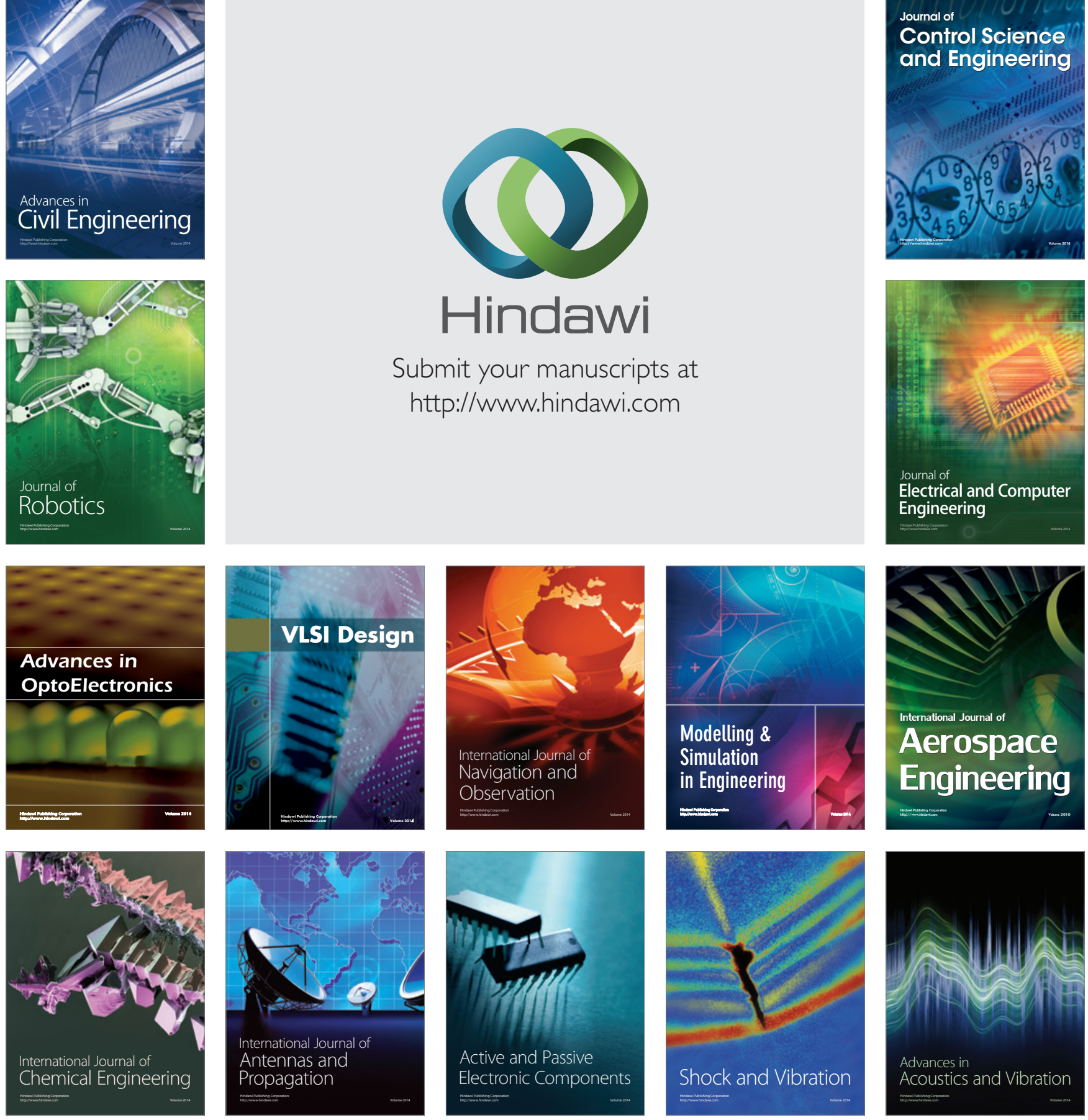